\title{
A.B. HOBAK
}

Анна Валеріївна Новак, кандидат історичних наук, доцент Східноєвропейського університету управління і менеджменту*

ORCID: 0000-0003-2499-4153

\section{ЗАКОНОДАВЧЕ ЗАБЕЗПЕЧЕННЯ ВИКОНАННЯ АЛІМЕНТНИХ ЗОБОВ'ЯЗАНЬ ЩОДО ДИТИНИ В УКРАЇНІ}

Постановка проблеми. Кожна людина наділена невід'ємними правами і має певні обов'язки, які чітко регламентовані на законодавчому рівні. Обов'язки особи визначаються не лише правилами соціального співжиття та загальноприйнятими моральними нормами і є загальними для всіх, а й визначаються індивідуально, залежно від того, яке особа займає соціальне становище, який має рід занять, професійну приналежність тощо (власне, так само, як і права).

Сім'я - це одна із соціальних цінностей, це сфера, яка потребує захисту як з боку ії членів, так і з боку держави. Особа, яка має сім’ю, окрім іншого, має обов'язки, що визначаються їі проживанням у сім'ї. Ці обов'язки чітко визначаються у сімейному законодавстві (Сімейному кодексі), норми якого регулюють окремі аспекти сімейних відносин. Зокрема, сімейним законодавством (ст. 180 СК України) встановлюється обов'язок батьків утримувати своїх неповнолітніх (а в окремих визначених законом випадках - і повнолітніх) дітей, забезпечуючи їм належне матеріальне становище.

Але не завжди сімейне законодавство має достатньо важелів впливу для того, щоб забезпечити виконання батьками вказаного обов'язку, а тому не може гарантувати, що права дитини щодо отримання належного матеріального забезпечення не будуть порушені. Це стосується як випадків, коли батьки не виконують обов'язок по утриманню дітей, проживаючи родиною, так і випадків, коли той із батьків, який не проживає 3 дитиною, не сплачує присуджені йому кошти на утримання дитини іншим із батьків.

Дана проблема є дійсно актуальною, оскільки велика кількість платників аліментів ухиляється від сплати коштів на утримання дитини. Як свідчать статистичні дані Єдиного реєстру боржників, на даний момент кількість офіційно зареєстрованих боржників зі сплати аліментів становить 169974 людини ${ }^{1}$. При цьому потрібно пам'ятати, що не всі особи звертаються у державні органи 3 приводу того, що особа, яка повинна сплачувати аліменти на утримання дитини, ухиляється від цього обов'язку.

Не зважаючи на те, що сімейне законодавство містить окремі норм, які чітко регламентують зобов'язання щодо утримання дітей, ця галузь самостійно не здатна забезпечити їх виконання. Тому для виконання цієї функції у інших галузях чинного законодавства України є норми, які визначають примусові заходи державного впливу, спрямовані на забезпечення дотримання права дитини на належне матеріальне забезпечення. Йдеться наразі про цивільне та кримінальне законодавство.

Але виникає питання: чи дійсно норми, які включені в чинне законодавство України різних галузей права, повною мірою забезпечують виконання обов'язку щодо утримання дитини, чи є ці норми дієвими і ефективними? Ці питання залишаються відкритими і вимагають детального вивчення 3 метою підвищення ефективності забезпечення виконання вказаних зобов'язань.

Аналіз останніх досліджень і публікацій. Питання, пов'язані із виконанням обов'язків щодо утримання дитини (аліментні зобов'язання), були предметом дослідження не одного вченого. Так, зокрема, дані питання стали предметом досліджень таких вчених, як М.В. Антокольська, Л.В. Афанасьєва, Г.П. Гришина, А.А. Епрікан, Л.В. Красіцька, І.А. Лакей, Т.М. Малярчук, М.Г. Масевич, З.В. Ромовська, Л.В. Сапейко, I.B. Труба, I.В. Чеховська та інші. Хоча на сучасному етапі даній проблемі присвячено, на наш погляд, недостатньо уваги.

Формулювання мети статті. 3 огляду на вказане вище метою даного дослідження є визначення особливостей законодавчого забезпечення виконання обов'язку щодо утримання дітей і встановлення повноти та рівня конкретизації такого забезпечення в Україні.

Виклад основного матеріалу. Насамперед потрібно визначитися із тим, що передбачають «зобов” язання по утриманню дитини», які саме обов'язки мають на увазі під цим терміном.

Утримання може бути як добровільним, так і примусовим (за рішенням суду від імені держави). Але у сімейному законодавстві та теорії права немає чіткого розмежування між цими двома видами утримання. Що стосується термінології, яка використовується у СК України, то, виходячи із змісту ст. 75 та ст. 181, поняття «утримання» та «аліменти» ототожнюється. Хоча насправді це не зовсім так.

Утримання - це обов'язок одних членів сім'ї доглядати, забезпечувати інших членів сім'ї засобами для існування, який виконується як добровільно, так і примусово в разі виникнення права на утримання в когось iз учасників сімейних правовідносин, який не здатен утримувати себе самостійно ${ }^{2}$. Тобто утримання - це

(C) А.В. Новак, 2020

* Anna Novak, Ph.D. in Law, Associate Professor of the Eastern European University Economics and Management 
обов'язок забезпечити засобами для існування одними учасниками сімейних правовідносин учасників, які не можуть робити це самостійно.

У сімейному законодавстві використовується також поняття «аліменти». Виходячи із теорії права, аліменти - це певна сума, яку має виплачувати той член подружжя іншому (дитині той із батьків), який проживає окремо, що призначається судом ${ }^{3}$. У законодавстві цей термін використовується саме у тих випадках, коли йдеться про примусове стягнення коштів на утримання іншого члена сім'ї, а не просто про встановлений обов'язок з утримання.

Тобто ототожнення понять «утримання» та «аліменти» є недоцільним. Отже, поняття «аліменти» та «утримання» перебувають у відносинах підпорядкування, оскільки «утримання» є більш широким поняттям, а поняття «аліменти» входять у поняття «утримання», але не вичерпує його 4 . У даному дослідженні ми будемо використовувати поняття «аліменти», оскільки досліджуватиметься саме забезпечення на законодавчому рівні виконання обов'язку щодо утримання дитини тим із батьків, хто проживає окремо, тобто саме про примусове виконання таких зобов'язань, оскільки за умов добровільного виконання цих зобов'язань потреба у законодавчому забезпеченні цього процесу не виникає.

Обов'язок щодо утримання стосується таких членів сім'ї, як: утримання одним із подружжя іншого (враховуючи випадки, коли чоловік та жінка не перебували у законному шлюбі) за умови наявності обставин, визначених нормами Глави 9 СК України, у тому числі на підставі положень шлюбного договору; утримання повнолітніми дітьми (дочкою, сином) своїх непрацездатних батьків (Глава 17 СК України); утримання батьками (батьком, матір’ю) дитини як неповнолітніх (Глава 15 СК України), так і повнолітніх (Глава 16 СК України); утримання опікуном чи піклувальником дітей (ст. 246 СК України); прийомними батьками прийомних дітей (Глава 201); утримання дідом, бабою своїх неповнолітніх онуків (ст. 265 СК України) та онуками своїх непрацездатних діда, бабу (ст. 266 СК України); утримання неповнолітніх братів, сестер (ст. 267 СК України) тощо. У даному дослідженні ми приділимо увагу проблемі законодавчого забезпечення виконання аліментних зобов'язань одним із батьків, що не проживає окремо, щодо утримання своєї дитини (дітей).

Згідно зі ст. 180 СК України, батьки зобов'язані утримувати дитину до досягнення нею повноліття. Стаття 181 СК України містить вказівку, що той із батьків, хто не проживає 3 дитиною, може брати участь у iii вихованні та утриманні, за домовленістю із тим з батьків, з ким проживає дитини (ч. 2 ст. 181 СК України), а також за рішенням суду, який визначає частку доходу платника аліментів, які можуть бути стягнені на утримання дитини. Також норми СК України (Глава 15) визначають порядок стягнення залежно від обставин, час, з якого починається стягнення аліментів, і коли закінчується, розмір аліментів у твердій грошовій сумі, порядок розрахунку заборгованості за аліментами та порядок і строки її стягнення як щодо неповнолітньої дитини, так і щодо повнолітньої у встановлених законом випадках (Глава 16).

Але норми сімейного законодавства не можуть самостійно забезпечити виконання зобов'язань щодо сплати аліментів на утримання дитини, оскільки не передбачають жодних примусових заходів, що можуть бути застосовані до боржника за аліментними зобов'язаннями щодо дитини. Адже далеко не всі, хто зобов'язаний сплачувати аліменти на утримання дитини, робить це вчасно і у повному обсязі (про що свідчать норми СК України щодо порядку розрахунку заборгованості та пені щодо аліментних зобов'язань). Деякі з таких осіб умисно переховуються і ухиляються усіма можливими способами від виконання вказаного обов'язку щодо дитини. Натомість цивільне законодавство містить низку норм 3 певними положеннями щодо регулювання аліментних зобов'язань. Так, зокрема, ЦК України визначає порядок, при якому заборгованість за аліментами списується з рахунку платника (боржника) у першу чергу. Але більше ніяких норм, які б визначали порядок і забезпечення вчасної слати аліментів на утримання дитини, цивільне законодавство України не містить.

Конкретизовану процедуру стягнення аліментів, заборгованості за аліментами на утримання дитини визначають норми Закону України «Про виконавче провадження» ${ }^{5}$. У даному нормативно-правовому акті чітко розписана процедура стягнення аліментів із боржника, накладення штрафу, порядку накладання арешту на майно і кошти боржника, строки, розподіл стягнених із боржника сум, обмеження, які можуть бути накладені на боржника, і у яких випадках. Відповідно до ч. 9 ст. 71 «Порядок стягнення аліментів» вказаного Закону до боржника застосовують низку обмежень (заборона виїзду за межі України, права на управління транспортним засобом, права на володіння зброєю та на полювання), які знімаються лише тоді, коли заборгованість буде погашена у повному обсязі.

Але найбільш суворі засоби примусу у випадку, якщо особа злісно не виконує покладені на неї зобов'язання щодо утримання дитини і регулярно ухиляється від цього, передбачені у інших нормативноправових актах. Йдеться насамперед про кримінальне законодавство, тобто про кримінально-правові заходи впливу на особу, яка є злісним неплатником аліментів. Небезпідставно вважається, що притягнення до кримінальної відповідальності за вчинення протиправного діяння $є$ найбільш суворим засобом впливу на порушника з боку держави, який, окрім всього, тягне негативні наслідки не лише у виді обмеження майнових чи особистих прав і свобод, а й у виді судимості, яку має особа вже після відбування нею покарання. Так, зокрема, щодо осіб, які ухиляються від сплати аліментів на утримання дитини, передбачена відповідальність за ст. 164 КК України, в якій зазначено, що кримінально караним $є$ злісне ухилення від сплати встановлених рішенням суду коштів на утримання дітей (аліментів), а також злісне ухилення батьків від утримання неповнолітніх або непрацездатних дітей, що перебувають на їх утриманні (ч. 1), а кваліфікуючим є вчинення вказаних діянь особою, раніше судимою за кримінальне правопорушення, передбачене цією статтею (ч. 2). У Примітці до цієї норми вказано, що під злісним ухиленням від сплати коштів на утримання дітей (алімен- 
тів) слід розуміти будь-які діяння боржника, спрямовані на невиконання рішення суду (приховування доходів, зміну місця проживання чи місця роботи без повідомлення державного виконавця, приватного виконавця тощо), які призвели до виникнення заборгованості із сплати таких коштів у розмірі, що сукупно становлять суму виплат за три місяці відповідних платежів. Ми вважаємо, що таких санкцій за ухилення від сплати аліментів цілком достатньо за умови, що зобов'язання щодо сплати аліментів на утримання дитини і порядок їх виконання чітко прописані у інших, більш спеціалізованих галузях права.

Отже, аналіз чинного законодавства щодо забезпечення виконання аліментних зобов'язань утримання дитини дає змогу стверджувати, що воно є достатньо конкретизованим та визначає максимально повно примусові заходи, які можуть застосовуватися до боржника. Хоча ми вважаємо, що потрібно дещо конкретизувати у чинному законодавстві. Зокрема, доцільно доповнити ст. 196 «Відповідальність за прострочення сплати аліментів, оплати додаткових витрат на дитину» СК України, додавши ч. 5, у якій вказати: «Якщо сума заборгованості перевищує сукупно суму виплат за три місяці, до платника аліментів застосовуються обмеження, передбачені частиною дев'ятою ст. 71 Закону «Про виконавче провадження»» та ч. 6, в якій вказати: «За злісне ухилення від сплати аліментів платник аліментів несе відповідальність, передбачену ст. 164 Кримінального кодексу України». Така вказівка позбавить платників аліментів ілюзії безкарності за ухилення від сплати аліментів на утримання дитини.

Висновки. Таким чином, проведене дослідження дає змогу зробити висновок про те, що поняття «утримання» та «аліменти» не тотожні, а співвідносяться як частина і ціле, оскільки «утримання» є більш широким поняттям, а поняття «аліменти» входять у поняття «утримання», але не вичерпує його. Тому у тих випадках, коли йдеться про законодавче забезпечення своєчасного і повного стягнення з платника (боржника) коштів на утримання дитини у примусовому порядку, говорять саме про аліментні зобов'язання, і це чітко враховано законодавцем.

Чинне законодавство по забезпеченню виконання аліментних зобов'язань щодо утримання дітей є достатньо конкретизованим та визначає максимально повно примусові заходи, які можуть застосовуватися до боржника, хоча і воно не є досконалим. 3 метою удосконалення вітчизняного законодавства, а також для того, щоб позбавити платників аліментів ілюзії безкарності за ухилення від сплати аліментів на утримання дитини, пропонуємо внести деякі уточнення у ст. 196 «Відповідальність за прострочення сплати аліментів, оплати додаткових витрат на дитину» Сімейного кодексу України, додавши ч. 5 та ч. 6, в яких вказати наслідки несплати аліментів вчасно та у повному обсязі.

Дане дослідження не вичерпує проблему законодавчого забезпечення виконання зобов'язань 3 виплати аліментів на утримання дитини в Україні і створює підгрунтя для подальших досліджень у даній сфері та вироблення рекомендацій, які підвищать ефективність чинного законодавства у цій сфері.

\footnotetext{
1 Єдиний реєстр боржників / Заборгованість по аліментах. URL: https://erb.minjust.gov.ua/\#/search-debtors

2 Труба В.І. Аліментні правовідносини: види та правова природа. Вісник ОНУ ім. I.I. Мечнікова. 2014. Т. 19. Вип. 3 (24). С. 45 (Серія «Правознавство»).

3 Сімейне право: Нотаріат. Адвокатура. Суд: наук.-практ. посіб.: у 2 кн. Л.Ю. Драгнєвич, О.С. Пульнєва, Є.І. Фурса, С.Я. Фурса та ін. ; за заг. ред. С.Я. Фурси. Київ: Видавець Фурса С.Я., 2005. Кн. 1. С. 560.

4 Лакей I.А., Чеховська І.В. Аліментне зобов'язання на утримання дитини як вид сімейного правовідношення. Порівняльно-аналітичне право. 2016. № 4. С. 89.

5 Про виконавче провадження: Закон України. Відомості Верховної Ради (BВP). 2016. № 30. Ст. 542. URL: https://zakon. rada.gov.ua/laws/show/1404-19\#n387
}

\section{Резюме}

Новак А.В. Законодавче забезпечення виконання аліментних зобов'язань щодо дитини в Україні.

Статтю присвячено питанню законодавчого забезпечення виконання аліментних зобов'язань по утриманню дитини в Україні. Аналіз чинного законодавства України показав, що воно є достатньо конкретизованим та визначає максимально повно примусові заходи, які можуть застосовуватися до боржника, хоча воно і не позбавлене недоліків. У зв'язку з цим нами запропоновано внести зміни у Сімейний кодекс України. Встановлено, що тих випадках, коли йдеться про законодавче забезпечення своєчасного і повного стягнення з платника (боржника) коштів на утримання дитини у примусовому порядку, говорять саме про аліментні зобов'язання, і це чітко враховано законодавцем.

Ключові слова: аліментні зобов'язання, зобов'язання утримання, платник аліментів, боржник, сімейне законодавство.

\section{Резюме}

\section{Украине.}

Новак А.В. Законодательное обеспечение исполнения алиментных обязательств по содержанию ребенка в

Статья посвящена вопросу законодательного обеспечения исполнения алиментных обязательств по содержанию ребенка в Украине. Анализ действующего законодательства Украины показал, что оно является достаточно конкретизированным и определяет максимально полно меры принуждения, которые могут применяться к должнику, хотя оно и не лишено недостатков. В связи с этим мы предложили внести изменения в Семейный кодекс Украины. Установлено, что в тех случаях, когда речь идет о законодательном обеспечении своевременного и полного стягивания с плательщика (должника) средств на содержание ребенка в принудительном порядке, речь идет именно об алиментных обязанностях, и это четко учтено законодателем.

Ключевые слова: алиментные обязательства, обязанности содержания, плательщик алиментов, должник, семейное законодательство. 


\section{Summary}

Anna Novak. Legislative support for the maintenance of alimentary obligations for child in Ukraine.

Family law establishes the obligation of parents to maintain their minor (and in some cases specified by law - adult) children, providing them with a proper financial situation. However, family law does not always have sufficient leverage to ensure that parents fulfill this obligation, and therefore cannot guarantee that the child's rights to adequate material support will not be violated. This problem is really relevant because a large number of alimony payers evade paying child support.

The purpose of this study is to determine the features of the legislative provision of the obligation to maintain children and to establish the completeness and level of specification of such provision in Ukraine.

According to the family law of Ukraine, parents are obliged to support the child until he or she reaches the age of majority. But not everyone who is required to pay child support does so on time and in full. Some of these individuals are deliberately hiding and evading the child in any way possible.

The concepts of "maintenance" and "alimony" are not identical, but are correlated as part and whole, because "maintenance" is a broader concept, and the concept of "alimony" is included in the concept of "maintenance", but does not exhaust it. Therefore, in cases where it is a question of legislative provision of timely and full recovery from the payer (debtor) of funds for the maintenance of a child under duress, it is a question of alimony obligations, and this is clearly taken into account by the legislator.

The current legislation to ensure the maintenance of child support obligations is quite specific and defines as fully as possible the coercive measures that can be applied to the debtor, although it is not perfect. In order to improve domestic legislation, as well as to deprive alimony payers of the illusion of impunity for evading child support, we propose to make some clarifications to family law.

This study does not address the problem of legislative enforcement of child support obligations in Ukraine and provides a basis for further research in this area and the development of new recommendations that will increase the effectiveness of existing legislation in this area.

Key words: alimentary obligations, maintenance obligations, alimony payer, debtor, family law.

DOI: 10.36695/2219-5521.2.2020.44

УДК 34.01

\section{Н.А. ОПАНАСЮК, І.Л. МЕЛЬНИК}

Наталія Анатоліївна Опанасюк, кандидат юридичних наук, доцент Національного університету фрізичного виховання і спорту України*

ORCID: 0000-0001-7418-8622

Ірина Леонідівна Мельник, кандидат економічних наук, доцент Національного університету харчових технологій ${ }^{* *}$

ORCID: 0000-0002-0729-2056

\section{НОРМИ ТУРИСТИЧНОГО ПРАВА УКРАЇНИ: ПОНЯТТЯ, ОЗНАКИ ТА СТРУКТУРА}

Постановка проблеми. Сучасні політико-правові й суспільно-економічні процеси та глобальні виклики призводять до істотних змін у законотворенні й актуалізують проблеми формування, розвитку, організації та функціонування комплексних галузей права в правовій системі України. Це об` єктивно детермінує суттєві зміни у системі права, появі в ній нових галузей, інтегративних правових утворень, у тому числі й міжгалузевого характеру. Серед них важливу роль відведено сукупності правових норм, які регулюють суспільні відносини в сфері туризму. Акумулюючи різні види діяльності щодо створення, розподілу, обміну та споживання туристичного продукту, а також відповідні ресурси, ринки, суспільні інститути, розширюється коло об єктів правового регулювання та, як наслідок, формується відносно самостійна нова галузь права - туристична. У цьому контексті логічним вважається дослідження його первинної категорії - норми туристичного права. Відтак, важливим науковим завданням $є$ визначення поняття, ознак і структури норм туристичного права, а також здійснення класифікації туристичних норм за різними ознаками.

Аналіз останніх досліджень і публікацій. У вітчизняній науці до проблематики галузеутворення, системи права та розвитку й становлення комплексних галузей права зверталися такі вчені, як С.С. Алексєєв, А.Г. Бобкова, А.П. Гетьман, Л.М. Добробог, А.А. Заєць, М.І. Козюбра, В.В. Костицький, В.В. Копейчіков, Т.Є. Маруховська, Ю.М. Оборотов, А.Ю. Олійник, Н.М. Оніщенко, В.Ф. Опришко, В.Ф. Погорілко, П.М. Рабінович, В.М. Селіванов, В.О. Сєрьогін, О.Ф. Скакун, Я.М. Шевченко, Ю.С. Шемшученко, Т.П. Чубко, O.I. Ющик та інші.

Дослідженням питань системи права та галузей права займалися також і зарубіжні науковці, а саме: А. Кауфман, А. Клаус, М. Крілє, Р. Леже, М. Лєсаж, Ф. Мастронарді, У. Твайнінг, А. Уілсон, Н. Філіпсен, М. Фуаре та інші.

(C) Н.А. Опанасюк, І.Л. Мельник, 2020

* Nataliia Opanasiuk, Ph.D. in Law, Associate Professor of the National University of Ukraine on Physical Education and Sport

** Iryna Melnyk, Ph.D. in Economic, Associate Professor of the National University of Food Technologies 